Kazuhisa Miyoshi, Bradley A. Lerch, Susan L. Draper, and Sai V. Raj Glenn Research Center, Cleveland, Ohio 
Since its founding, NASA has been dedicated to the advancement of aeronautics and space science. The NASA Scientific and Technical Information (STI) Program Office plays a key part in helping NASA maintain this important role.

The NASA STI Program Office is operated by Langley Research Center, the Lead Center for NASA's scientific and technical information. The NASA STI Program Office provides access to the NASA STI Database, the largest collection of aeronautical and space science STI in the world. The Program Office is also NASA's institutional mechanism for disseminating the results of its research and development activities. These results are published by NASA in the NASA STI Report Series, which includes the following report types:

- TECHNICAL PUBLICATION. Reports of completed research or a major significant phase of research that present the results of NASA programs and include extensive data or theoretical analysis. Includes compilations of significant scientific and technical data and information deemed to be of continuing reference value. NASA's counterpart of peerreviewed formal professional papers but has less stringent limitations on manuscript length and extent of graphic presentations.

- TECHNICAL MEMORANDUM. Scientific and technical findings that are preliminary or of specialized interest, e.g., quick release reports, working papers, and bibliographies that contain minimal annotation. Does not contain extensive analysis.

- CONTRACTOR REPORT. Scientific and technical findings by NASA-sponsored contractors and grantees.
- CONFERENCE PUBLICATION. Collected papers from scientific and technical conferences, symposia, seminars, or other meetings sponsored or cosponsored by NASA.

- SPECIAL PUBLICATION. Scientific, technical, or historical information from NASA programs, projects, and missions, often concerned with subjects having substantial public interest.

- TECHNICAL TRANSLATION. Englishlanguage translations of foreign scientific and technical material pertinent to NASA's mission.

Specialized services that complement the STI Program Office's diverse offerings include creating custom thesauri, building customized data bases, organizing and publishing research results ... even providing videos.

For more information about the NASA STI Program Office, see the following:

- Access the NASA STI Program Home Page at http://www.sti.nasa.gov

- E-mail your question via the Internet to help@sti.nasa.gov

- Fax your question to the NASA Access Help Desk at 301-621-0134

- Telephone the NASA Access Help Desk at 301-621-0390

- Write to: NASA Access Help Desk NASA Center for AeroSpace Information 7121 Standard Drive Hanover, MD 21076 


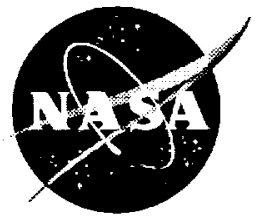

\section{Evaluation of Ti-48Al-2Cr-2Nb \\ Under Fretting Conditions}

Kazuhisa Miyoshi, Bradley A. Lerch, Susan L. Draper, and Sai V. Raj Glenn Research Center, Cleveland, Ohio

Prepared for the

Third International Symposium on Fretting Fatigue sponsored by the American Society for Testing and Materials

Nagaoka-shi, Japan, May 15-18, 2001

National Aeronautics and

Space Administration

Glenn Research Center 


\section{Acknowledgments}

The authors are grateful to Dr. Gary R. Halford and Dr. Michael V. Nathal for very helpful discussions.

Trade names or manufacturers' names are used in this report for identification only. This usage does not constitute an official endorsement, either expressed or implied, by the National Aeronautics and Space Administration.

Available from

NASA Center for Aerospace Information 7121 Standard Drive

Hanover, MD 21076
National Technical Information Service 5285 Port Royal Road Springfield, VA 22100

Available electronically at http://gltrs.grc.nasa.gov/GLTRS 


\title{
Evaluation of Ti-48Al-2Cr-2Nb Under Fretting Conditions
}

\author{
Kazuhisa Miyoshi, Bradley A. Lerch, Susan L. Draper, and Sai V. Raj \\ National Aeronautics and Space Administration \\ Glenn Research Center \\ Cleveland, Ohio 44135
}

\begin{abstract}
The fretting behavior of Ti-48Al-2Cr-2Nb $(\gamma-\mathrm{TiAl})$ in contact with the nickelbase superalloy $718^{\mathrm{b}}$ was examined in air at temperatures from 296 to $823 \mathrm{~K}$ (23 to $550^{\circ} \mathrm{C}$ ). The interfacial adhesive bonds between $\mathrm{Ti}-48 \mathrm{Al}-2 \mathrm{Cr}-2 \mathrm{Nb}$ and superalloy 718 were generally stronger than the cohesive bonds within $\mathrm{Ti}-48 \mathrm{Al}-2 \mathrm{Cr}-2 \mathrm{Nb}$. The failed Ti-48Al-2Cr-2Nb debris subsequently transferred to the superalloy 718 . In reference experiments conducted with $\mathrm{Ti}-6 \mathrm{Al}-4 \mathrm{~V}$ against superalloy 718 under identical fretting conditions, the degree of transfer was greater for Ti-6Al-4V than for Ti-48Al-2Cr- $2 \mathrm{Nb}$. Wear of $\mathrm{Ti}-48 \mathrm{Al}-2 \mathrm{Cr}-2 \mathrm{Nb}$ generally decreased with increasing fretting frequency. The increasing rate of oxidation at elevated temperatures led to a drop in wear at $473 \mathrm{~K}$. However, fretting wear increased as the temperature was increased from 473 to $823 \mathrm{~K}$. At 723 and $823 \mathrm{~K}$, oxide film disruption generated cracks, loose wear debris, and pits on the $\mathrm{Ti}-48 \mathrm{Al}-2 \mathrm{Cr}-2 \mathrm{Nb}$ wear surface. Both increasing slip amplitude and increasing load tended to produce more metallic wear debris, causing severe abrasive wear in the contacting metals.
\end{abstract}

${ }^{a}$ Composition, at.\%: titanium, 47.9; aluminum, 48.0; niobium, 1.96; chromium, 1.94; carbon, 0.013 ; nitrogen, 0.014 ; and oxygen, 0.167 .

${ }^{\mathrm{b}}$ Composition, wt.\%: nickel, 50-55; chromium, 17-21; iron, 12-23; niobium plus tantalum, 4.75-5.5; molybdenum, 2.8-3.3; cobalt, 1 ; titanium, 0.65-1.15; aluminum, $0.2-0.8$; silicon, 0.35 ; manganese, 0.35 ; copper, 0.3 ; carbon, 0.08 ; sulfur, 0.015 ; phosphorus, 0.015 ; and boron, 0.006 . 


\section{Introduction}

Adhesion, a manifestation of mechanical strength over an appreciable area, has many causes, including chemical bonding, deformation, and the fracture processes involved in interface failure. A clean metal in contact with another clean metal will fail either in tension or in shear because some of the interfacial bonds are generally stronger than the cohesive bonds within the cohesively weaker metal [1]. The failed metal subsequently transfers material to the other contacting metal. Adhesion undoubtedly depends on the surface cleanliness; the area of real contact; the chemical, physical, and mechanical properties of the interface; and the modes of junction rupture. The environment influences the adhesion, deformation, and fracture behaviors of contacting materials in relative motion.

Clean surfaces can be created by repeated sliding in vacuum, making direct contact of the fresh, clean surfaces unavoidable in practical cases [2]. This situation also applies in some degree to sliding contact in air, where fresh surfaces are continuously produced on interacting surfaces in relative motion. Microscopically small, surface-parallel relative motion, which can be vibratory (in fretting or false brinnelling) or creeping (in fretting), produces fresh, clean interacting surfaces and causes junction (contact area) growth in the contact zone [3-5].

Fretting wear produced between contacting elements is adhesive wear taking place in a nominally static contact under normal load and repeated microscopic vibratory motion [6-10]. The most damaging effect of fretting is the possibly significant reduction in the fatigue capability of the fretted component, even though the wear produced by fretting appears to be quite mild [10]. For example, Hansson, et al. reported that the reduction in fatigue strength by fretting of $\mathrm{Ti}-47 \mathrm{Al}-2 \mathrm{Nb}-2 \mathrm{Mn}$ containing $0.8 \mathrm{vol} . \% \mathrm{TiB}_{2}$ was approximately 20 percent.

Fretting fatigue is a complex problem of significant interest to aircraft engine manufacturers [11-14]. Fretting failure can occur in a variety of engine components. Numerous approaches, depending on the component and the operating conditions, have been taken to address the fretting problem. The components of interest in this investigation were the low-pressure turbine blades and disks. The blades in this case were titanium aluminide and the disk was a nickel-base superalloy. A concern for these airfoils is the fretting in fitted interfaces at the dovetail where the blade and disk are connected. Careful design can reduce fretting in most cases, but not completely eliminate it, because the airfoils frequently have a skewed (angled) blade-disk dovetail attachment, which leads to a complex stress state. Further, the local stress state becomes more complex when the influence of the metal-metal contact and the edge of contact is evaluated.

Because titanium and titanium-base alloys in the clean state will exhibit strong adhesive bonds $[2,15]$ when in contact with themselves and other materials, this adhesion causes heavy surface damage and high friction in practical cases. Therefore, it is possible that fretting will be a serious concern in this application.

The objective of this investigation was to evaluate the extent of fretting damage on $\mathrm{Ti}-48 \mathrm{Al}-2 \mathrm{Cr}-2 \mathrm{Nb}(\gamma-\mathrm{TiAl})$ in contact with the nickel-base superalloy 718 at temperatures from 296 to $823 \mathrm{~K}$. Selected reference experiments were also conducted with Ti-6Al-4V. There is a large experience base with Ti-6 Al-4V, which has been used extensively as a compressor blade material. The parameters of microscopic, surface-parallel motion, such as fretting frequency, slip amplitude, and load, were systematically examined in this study. Scanning interference microscopy (noncontact optical profilometry) was used to evaluate 
surface characteristics, such as topography, roughness, material transfer, and wear volume loss. Scanning electron microscopy with energy-dispersive spectroscopy was used to determine the morphology and elemental composition of fretted surfaces, transferred material, and wear debris.

\section{Materials}

The Ti-48Al-2Cr-2Nb specimens were determined to be of the following composition (in atomic percent): titanium, 47.9; aluminum, 48.0; niobium, 1.96; chromium, 1.94; carbon, 0.013 ; nitrogen, 0.014 ; and oxygen, 0.167 . The tensile properties are shown in Table 1.

Table $1-$ Tensile Properties of Ti-48Al-2Cr-2Nb

\begin{tabular}{c|c|c}
\hline Temperature, $\mathrm{K}$ & Modulus, GPa & Ultimate tensile strength, MPa \\
\hline 293 & 170 & 410 \\
923 & 140 & 460 \\
\hline
\end{tabular}

The nickel-base superalloy 718 specimens were of the following nominal composition (in weight percent): nickel, 50-55; chromium, 17-21; iron, 12-23; niobium plus tantalum, 4.75-5.5; molybdenum, 2.8-3.3; cobalt, 1 ; titanium, 0.65-1.15; aluminum, $0.2-0.8$; silicon, 0.35 ; manganese, 0.35 ; copper, 0.3 ; carbon, 0.08 ; sulfur, 0.015 ; phosphorus, 0.015 ; and boron, 0.006 [16]. Superalloy 718 was solutioned and aged according to Aerospace Material Specification AMS 5596G, SAE, Warrendale, PA, 1987, yielding Rockwell C-scale hardness $H_{R C}$ of 36. The tensile properties [16] are shown in Table 2. The ultimate tensile strength of superalloy 718 is greater than that of $\mathrm{Ti}-48 \mathrm{Al}-2 \mathrm{Cr}-$ $2 \mathrm{Nb}$ by a factor of $\sim 3.5$ at room temperature and $\sim 2$ at high temperature $(\sim 1000 \mathrm{~K})$.

Table 2-Tensile Properties of Nickel-Base Superalloy 718

\begin{tabular}{c|c|c}
\hline Temperature, $\mathrm{K}$ & Modulus, $\mathrm{GPa}$ & Ultimate tensile strength, $\mathrm{MPa}$ \\
\hline 293 & 200 & 1434 \\
811 & 171 & 1276 \\
1033 & 154 & 758 \\
\hline
\end{tabular}

The reference Ti-6Al-4V specimens were of the following nominal composition (in weight percent): titanium, balance; aluminum, 5.5-6.75; vanadium, 3.5-4.5; iron, $\leq 0.30$; carbon, $\leq 0.08$; nitrogen, $\leq 0.05$; oxygen, $\leq 0.20$; and hydrogen, $\leq 0.015[17]$.

\section{Experiments}

Figure 1 presents the fretting wear apparatus used in this investigation. Fretting wear experiments were conducted with 9.4-mm-diameter, hemispherical nickel-base superalloy 718 pins in contact with $\mathrm{Ti}-48 \mathrm{Al}-2 \mathrm{Cr}-2 \mathrm{Nb}$ flats or with 6-mm-diameter, hemispherical $\mathrm{Ti}-48 \mathrm{Al}-2 \mathrm{Cr}-2 \mathrm{Nb}$ pins in contact with nickel-base superalloy 718 flats in air 


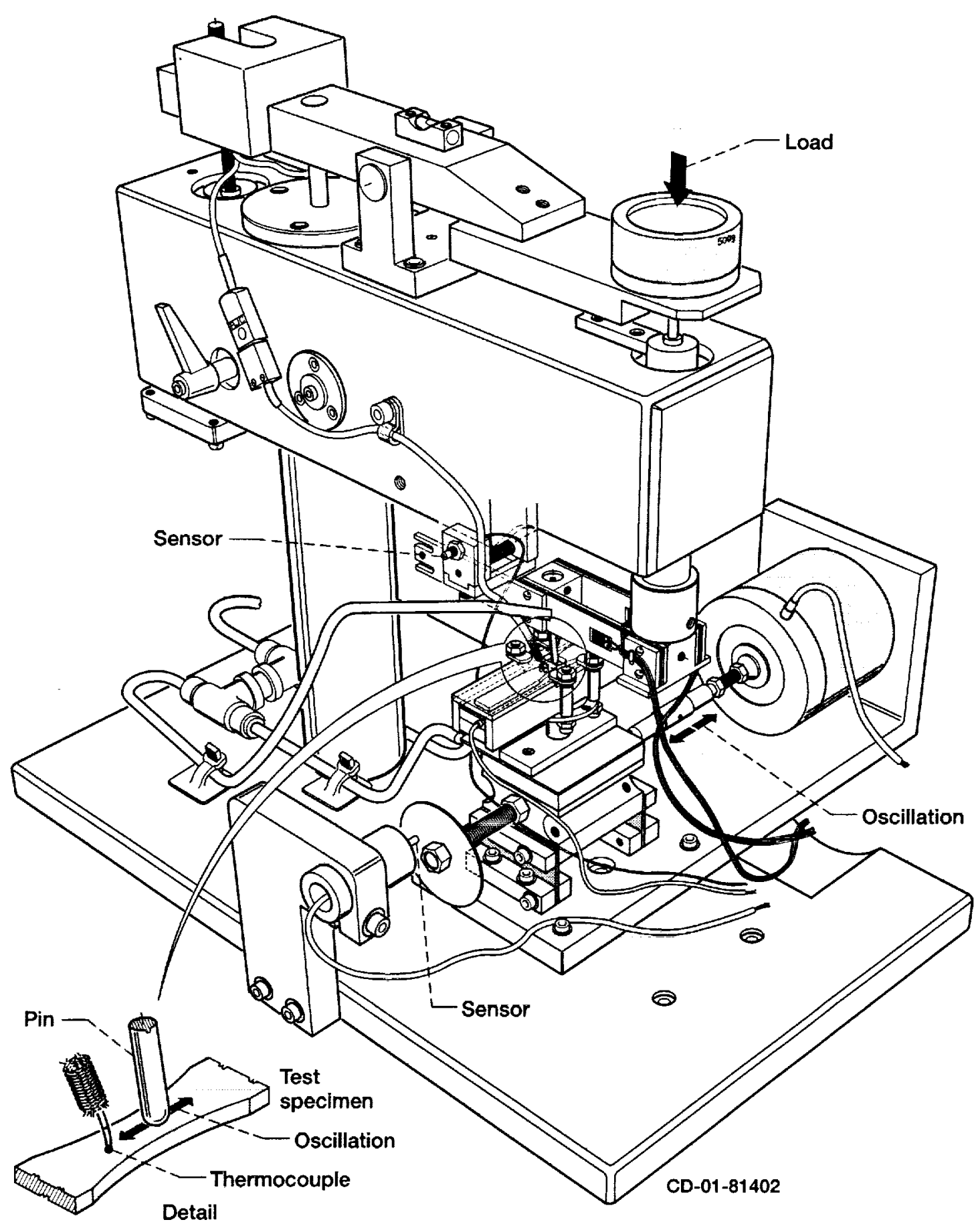

Figure I-Fretting apparatus.

at temperatures from 296 to $823 \mathrm{~K}$. All the flat and pin specimens used were polished with $3-\mu \mathrm{m}$-diameter diamond powder. Both pin and flat surfaces were relatively smooth, having centerline-average roughness $R_{a}$ in the range 18 to $83 \mathrm{~nm}$ (Table 3). The Vickers hardness, measured at a load of $1 \mathrm{~N}$, for the polished flat and pin specimens is also shown in Table 3. 
Table 3-Surface Roughness and Vickers Hardness of Specimens

\begin{tabular}{l|c|c|c|c}
\hline \multirow{2}{*}{ Specimen } & \multicolumn{2}{c|}{$\begin{array}{c}\text { Centerline-average } \\
\text { roughness, } R_{a}, \mathrm{~nm}\end{array}$} & \multicolumn{2}{c}{ Vickers hardness $^{\mathrm{a}}, H_{v}, \mathrm{GPa}$} \\
\cline { 2 - 5 } & Mean & $\begin{array}{c}\text { Standard } \\
\text { deviation }\end{array}$ & Mean & $\begin{array}{c}\text { Standard } \\
\text { deviation }\end{array}$ \\
\hline $\begin{array}{l}\text { 9.4-mm-diameter, } \\
\text { hemispherical, nickel-base } \\
\text { superalloy 718 pin }\end{array}$ & 40 & 8.9 & 5.52 & 0.44 \\
\hline $\begin{array}{l}\text { 6-mm-diameter, } \\
\text { hemispherical Ti-48Al-2Cr- }\end{array}$ & 42 & 7.1 & 4.12 & 0.42 \\
2Nb pin & & & 3.85 & 0.092 \\
\hline $\begin{array}{l}\text { 9.4-mm-diameter, } \\
\text { hemispherical Ti-6Al-4V pin }\end{array}$ & 83 & 2.0 & 3.78 & 0.57 \\
\hline Ti-48Al-2Cr-2Nb flat & 35 & 3.3 & 4.78 & 0.21 \\
\hline $\begin{array}{l}\text { Nickel-base superalloy 718 } \\
\text { flat }\end{array}$ & 18 & 7.2 & & \\
\hline
\end{tabular}

${ }^{\mathrm{a}}$ Load, $1 \mathrm{~N}$.

All fretting wear experiments were conducted at loads from 1 to $40 \mathrm{~N}$, frequencies of $50,80,120$, and $160 \mathrm{~Hz}$, and slip amplitudes between 50 and $200 \mu \mathrm{m}$ for 1 million to 20 million cycles. Both pin and flat surfaces were rinsed with 200-proof ethyl alcohol before installation in the fretting apparatus.

Two or three fretting experiments were conducted with each material couple at each fretting condition. The data were averaged to obtain the wear volume losses of $\mathrm{Ti}-48 \mathrm{Al}-$ $2 \mathrm{Cr}-2 \mathrm{Nb}$ and $\mathrm{Ti}-6 \mathrm{Al}-4 \mathrm{~V}$. The wear volume loss was determined by using an optical profiler (noncontact, vertical scanning, white-light interferometer). It characterizes and quantifies surface roughness, height distribution, and critical dimensions (such as area and volume of damage, wear scars, and topographical features). It has three-dimensional profiling capability with excellent precision and accuracy (e.g., profile heights ranging from $\leq 1 \mathrm{~nm}$ up to $5000 \mu \mathrm{m}$ with $0.1-\mathrm{nm}$ height resolution). The shape of a surface can be displayed by a computer-generated map developed from digital data derived from a threedimensional interferogram of the surface. A computer directly processes the quantitative volume and depth of a fretted wear scar. Reference fretting wear experiments were conducted with 9.4-mm-diameter hemispherical Ti-6Al-4V pins in contact with nickelbase superalloy 718 flats.

\section{Results and Discussion}

\section{Observations}

Surface and subsurface damage always occurred on the interacting surfaces of the Ti-48Al-2Cr-2Nb fretted in air. The surface damage consisted of material transfer, pits, oxides and debris, scratches, fretting craters and/or wear scars, plastic deformation, and cracks. 
Adhesion and Material Transfer-Figure 2 presents a backscattered electron image and an energy-dispersive X-ray spectrum (EDS) taken from the fretted surface of the nickel-base superalloy 718 pin after contact with the $\mathrm{Ti}-48 \mathrm{Al}-2 \mathrm{Cr}-2 \mathrm{Nb}$ flat. Clearly, Ti$48 \mathrm{Al}-2 \mathrm{Cr}-2 \mathrm{Nb}$ transferred to superalloy 718 . The Ti-48Al-2Cr-2Nb failed either in tension or in shear because some of the interfacial adhesive bonds (solid state or cold welding) were stronger than the cohesive bonds within the cohesively weaker Ti-48Al-2Cr-2Nb.
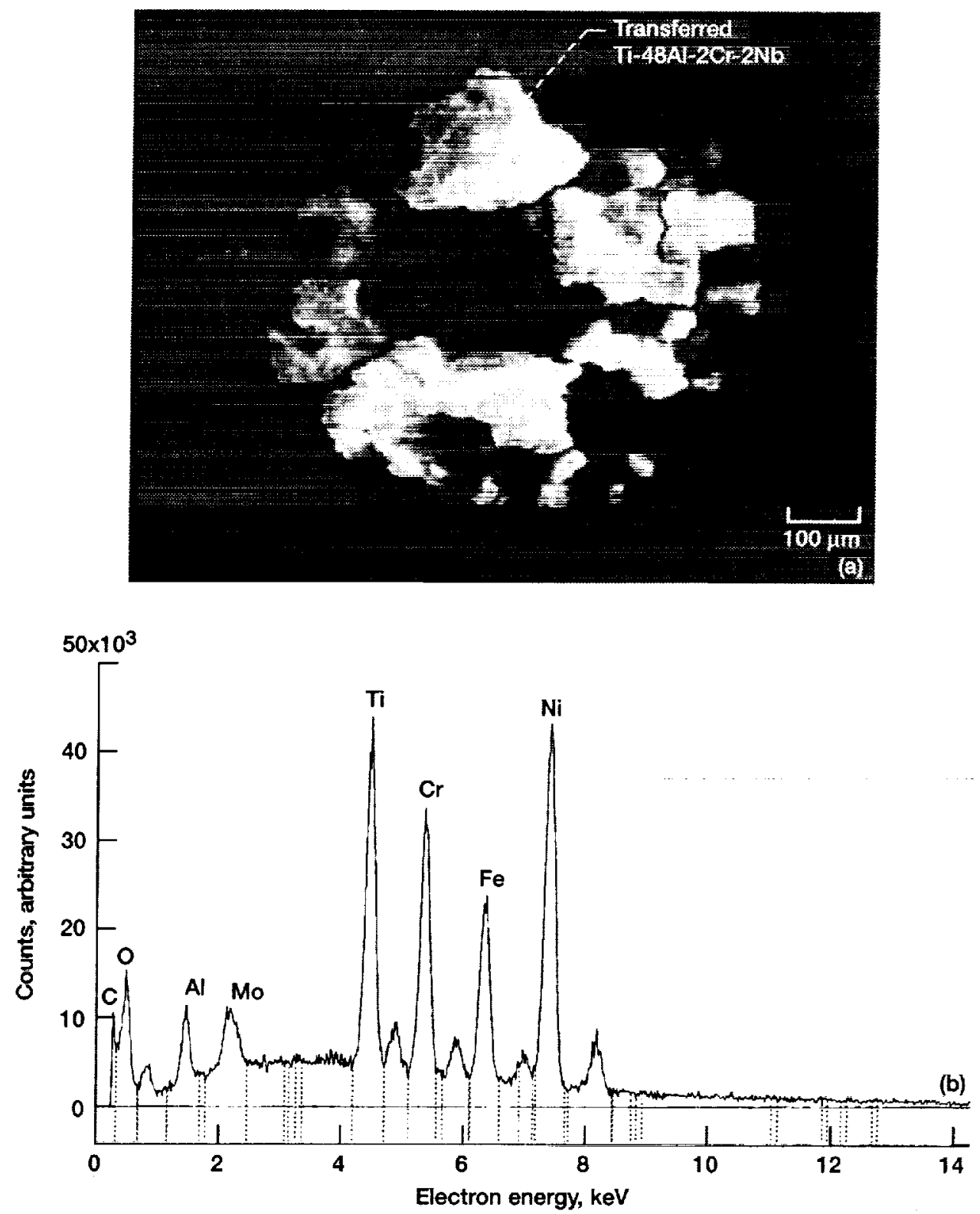

Figure 2-Wear scar on superalloy 718 pin fretted against $7 \mathrm{~T}-48 \mathrm{Al}-2 \mathrm{Cr}-2 \mathrm{Nb}$ flat. (a) SEM backscattered electron image. (b) $X$-ray energy spectrum with EDS. Fretting conditions: load, $1.5 \mathrm{~N}$; frequency, $80 \mathrm{~Hz}$; slip amplitude, $50 \mu \mathrm{m}$; total number of cycles, I million; environment, air; and temperature, $823 \mathrm{~K}$. 
The ultimate tensile strength of superalloy 718 is greater than that of $\mathrm{Ti}-48 \mathrm{Al}-2 \mathrm{Cr}-2 \mathrm{Nb}$ by a factor of $\sim 3.5$ at room temperature and $\sim 2$ at high temperature $(\sim 1000 \mathrm{~K})$. The failed Ti$48 \mathrm{Al}-2 \mathrm{Cr}-2 \mathrm{Nb}$ subsequently transferred to the superalloy 718 surface in amounts ranging from 10 to 60 percent of the superalloy 718 contact area at all fretting conditions in this study. The thickness of the transferred $\mathrm{Ti}-48 \mathrm{Al}-2 \mathrm{Cr}-2 \mathrm{Nb}$ ranged up to $\sim 20 \mu \mathrm{m}$.

As with the materials pair of $\mathrm{Ti}-48 \mathrm{Al}-2 \mathrm{Cr}-2 \mathrm{Nb}$ and superalloy 718 , material transfer was observed on the superalloy 718 flat surface after fretting against the Ti-6Al-4V pin at 696 and $823 \mathrm{~K}$ in air. However, the degree of material transfer was remarkably different and greater, ranging from 30 to 100 percent of the superalloy 718 contact area for identical fretting conditions. The thickness ranged up to $50 \mu \mathrm{m}$.

Fretting Wear-Figure 3 shows typical wear scars produced on the Ti-48Al-2Cr$2 \mathrm{Nb}$ pin and the superalloy 718 flat with fretting. Because of the specimen geometry a large amount of wear debris was deposited just outside the circular contact area. Pieces of the metals (both Ti-48Al-2Cr-2Nb and superalloy 718) and their oxides were torn out during fretting. It appears that the cohesive bonds in some of the contact area of both metals fractured. Scanning electron microscopy (SEM) and EDS studies of wear debris produced under fretting verified the presence of metallic particles of both Ti-48AI-2Cr- $2 \mathrm{Nb}$ and superalloy 718 . In the central region of wear scars produced on $\mathrm{Ti}-48 \mathrm{Al}-2 \mathrm{Cr}-2 \mathrm{Nb}$ there was generally a large, shallow pit, where $\mathrm{Ti}-48 \mathrm{Al}-2 \mathrm{Cr}-2 \mathrm{Nb}$ had torn out or sheared off and subsequently transferred to superalloy 718 . The central regions of wear scars produced on Ti-48Al-2Cr-2 $\mathrm{Nb}$ and on superalloy 718 were morphologically similar (Fig. 3), generally having wear debris, scratches, plastically deformed asperities, and cracks.
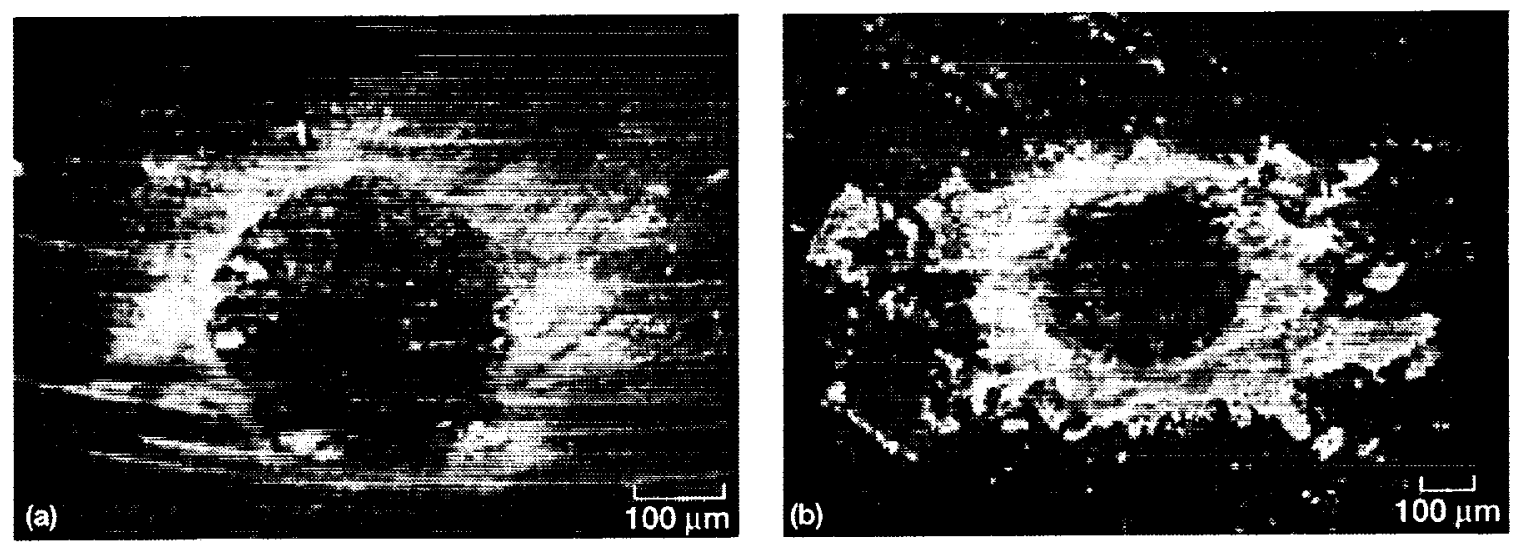

Figure 3-Wear scars (a) on Ti-48Al-2Cr-2Nb pin and (b) on superalloy 718 flat. Fretting conditions: load, I N; frequency; $80 \mathrm{~Hz}$; slip amplitude, $50 \mu \mathrm{m}$; total number of cycles, I million; environment, air; and temperature, $823 \mathrm{~K}$.

Figure 4 shows examples of surface damage: metallic wear debris of Ti-48Al-2Cr$2 \mathrm{Nb}$ and superalloy 718 , oxides and their debris, scratches (grooves), small craters, plastically deformed asperities, and cracks. The scratches (Fig. 4(a)) can be caused by hard protuberances (asperities) on the superalloy 718 surface (two-body conditions) or by wear particles between the surfaces (three-body conditions). Abrasion is a severe form of wear. The hard asperities and trapped wear particles plow or cut the Ti-48Al-2Cr-2Nb surface. The trapped wear particles have a scratching effect on both surfaces; and because they carry part of the load, they cause concentrated pressure peaks on both surfaces. The pressure 

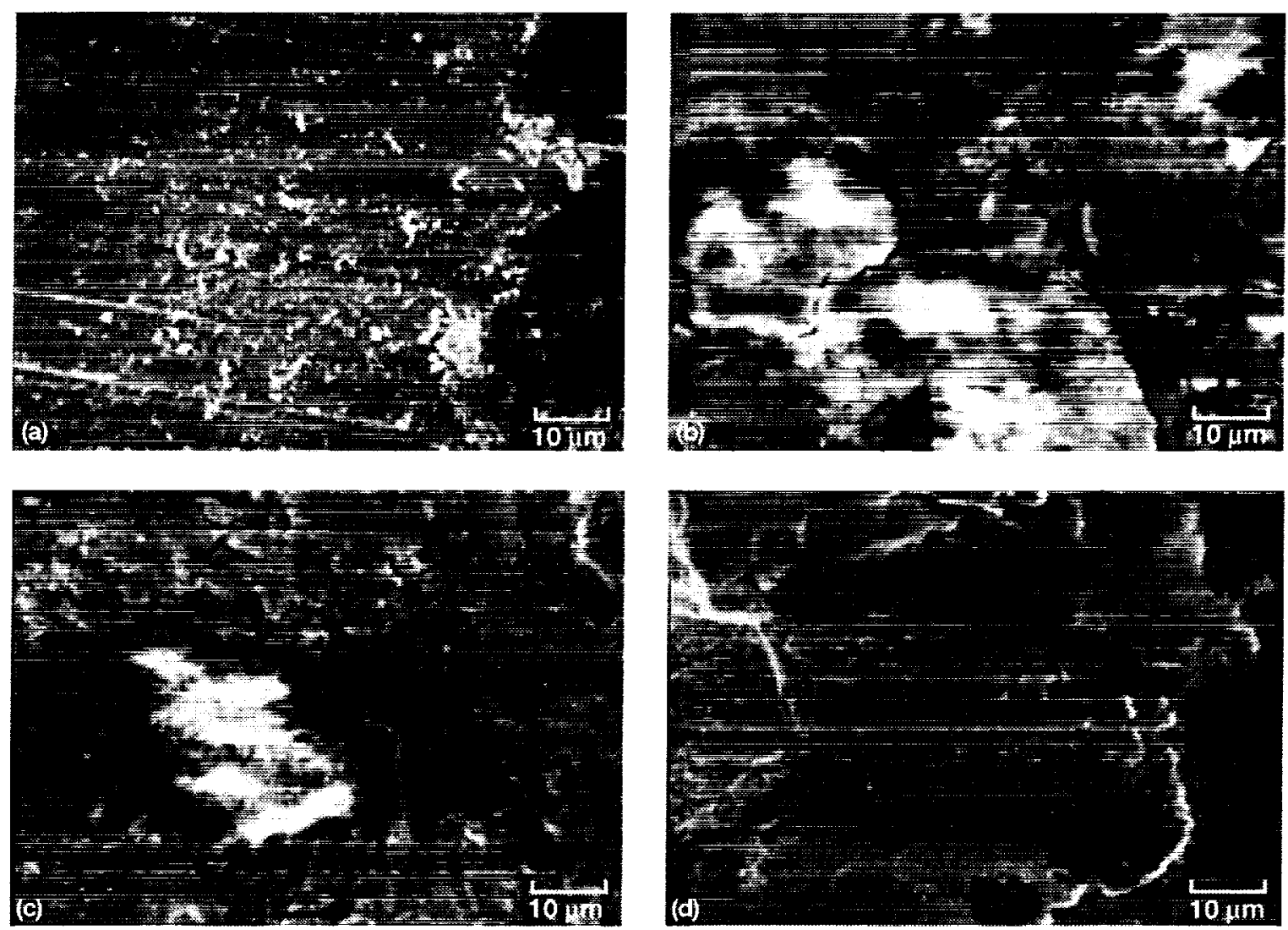

Figure 4-Surface and subsurface damage in $\mathrm{Ti}-48 \mathrm{Al}-2 \mathrm{Cr}-2 \mathrm{Nb}$ flat in contact with superalloy 718 pin. (a) Scratches. (b) Cracks in oxide layers. (c) Cracks in metal. (d) Fracture pits and plastic deformation. Fretting conditions: load, $1 \mathrm{~N}$; frequency, $80 \mathrm{~Hz}$; slip amplitude and total number of cycles: (a) $50 \mu \mathrm{m}$ and 1 million, (b) $60 \mu \mathrm{m}$ and 10 million, (c) $50 \mu \mathrm{m}$ and 1 million, (d) 70 um and 20 million; environment, air; and temperature, $823 \mathrm{~K}$.

peaks may well be the origin of crack nucleation in the oxide layers and the bulk alloys. Two types of crack were observed on the wear surface of Ti-48Al-2Cr-2Nb: cracks in the oxide layers, and cracks in the bulk $\mathrm{Ti}-48 \mathrm{Al}-2 \mathrm{Cr}-2 \mathrm{Nb}$.

Oxide layers readily form on the Ti-48Al-2Cr-2Nb surface at $823 \mathrm{~K}$ and are often a favorable solution to wear problems. However, if the bulk $\mathrm{Ti}-48 \mathrm{Al}-2 \mathrm{Cr}-2 \mathrm{Nb}$ is not hard enough to carry the load, it will deform plastically or elastically under fretting contact. With Ti-48Al-2Cr-2Nb, cracks occurred in the oxide layers both within and around the contact areas (Fig. 4(b)).

Fractures in the protective oxide layers produced cracks in the bulk $\mathrm{Ti}-48 \mathrm{Al}-2 \mathrm{Cr}$ $2 \mathrm{Nb}$ (Fig. 4(c)) and also produced wear debris; chemically active, fresh surfaces; plastic deformation; and craters or fracture pits (Fig. 4(d)). The wear debris caused third-body abrasive wear (Fig. 4(a)). Local, direct contacts between the fresh surfaces of Ti-48Al-2Cr$2 \mathrm{Nb}$ and superalloy 718 resulted in increased adhesion and local stresses, which may cause plastic deformation, flake-like wear debris, and craters (e.g., the fracture pits in the Ti48Al-2Cr-2Nb shown in Fig. 4(d)).

Cross sections of a wear scar on $\mathrm{Ti}-48 \mathrm{Al}-2 \mathrm{Cr}-2 \mathrm{Nb}$ revealed subsurface cracking and craters. For example, Fig. 5 shows propagation of subsurface cracking, nucleation of small cracks, formation of a large crater, and generation of debris. Cracks are transgranular and have no preference to the microstructure. 


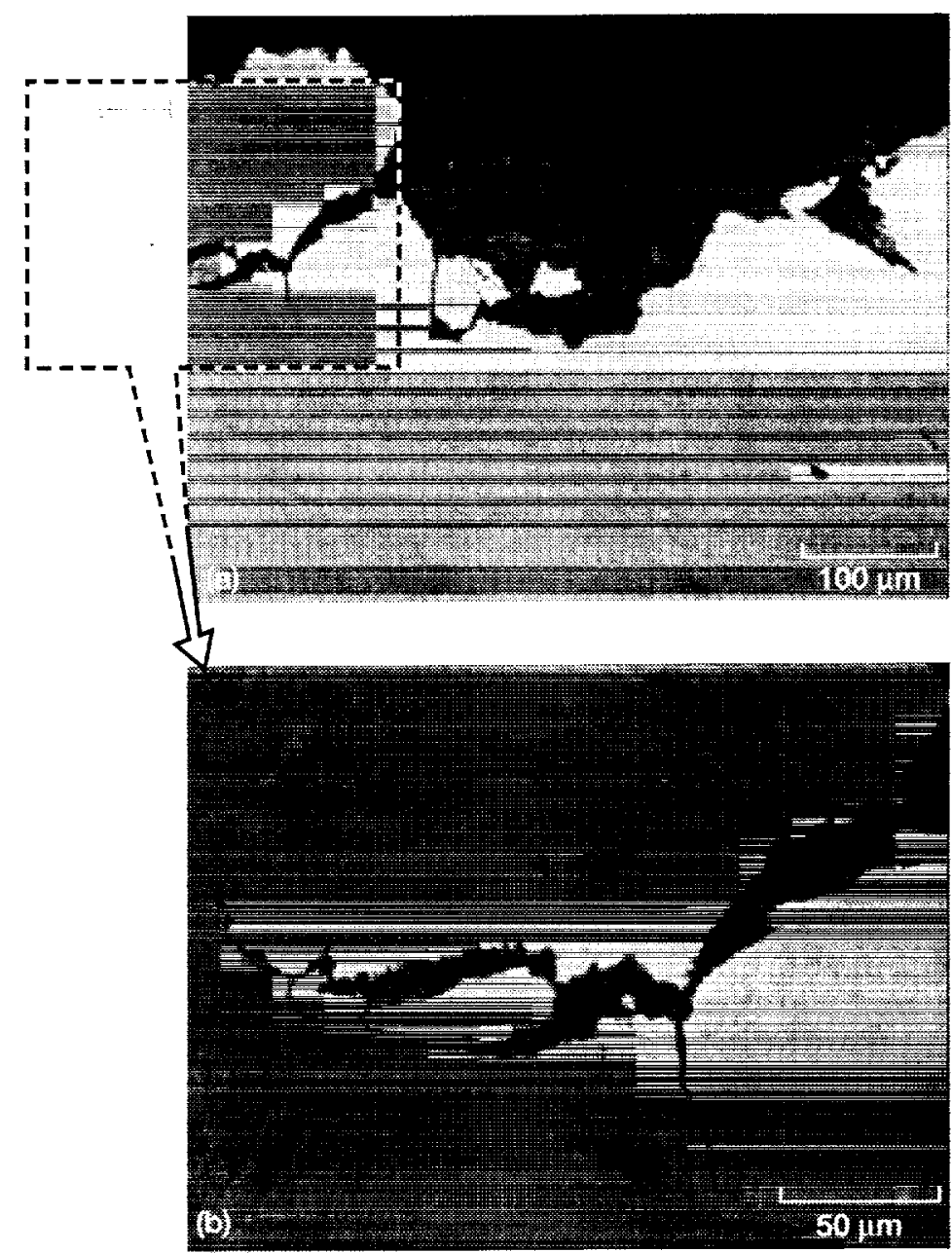

Figure 5-Cross-section view of wear scar on $7 \mathrm{i}-48 \mathrm{Al}-2 \mathrm{Cr}-2 \mathrm{Nb}$ flat in contact with superalloy 718 pin. (a) Overview: (b) Crack growth. Fretting conditions: load, $30 \mathrm{~N}$; frequency, $80 \mathrm{~Hz}$; slip amplitude, $70 \mu \mathrm{m}$; total number of cycles, 20 million; environment, air; and temperature, $823 \mathrm{~K}$.

Parameters Influencing Wear Loss of Ti-48Al-2Cr-2Nb

Figure 6 shows the wear volume loss measured by the optical interferometer as a function of fretting frequency for Ti-48Al-2Cr-2Nb in contact with superalloy 718 . Although there were some exceptions, the wear volume loss generally decreased with increasing fretting frequency. A reasonable amount of material transfer from the Ti-48Al$2 \mathrm{Cr}-2 \mathrm{Nb}$ specimen to the superalloy 718 specimen was observed at all frequencies. At the lowest frequency of $50 \mathrm{~Hz}$ remarkable plastic deformation (grooving) and surface roughening in the Ti-48Al-2Cr-2Nb wear scar were observed. At high frequencies wear scars were noticeably smooth with bulk cracks in the Ti-48Al-2Cr-2Nb surface. 


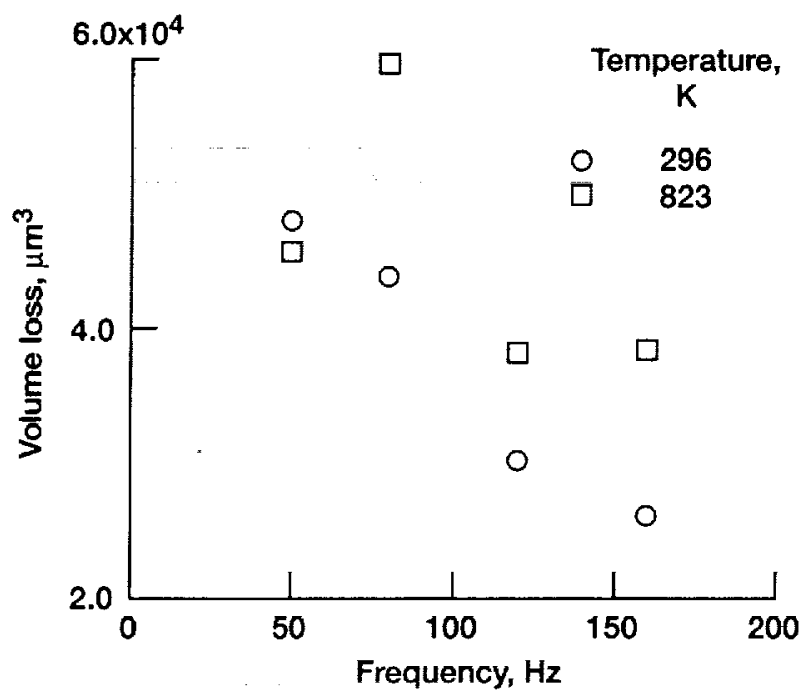

Figure 6-Wear volume loss of $\mathrm{Ti}-48 \mathrm{Al}-2 \mathrm{Cr}-2 \mathrm{Nb}$ flat in contact with superalloy 718 pin in air as function of fretting frequency. Fretting conditions: load, $30 \mathrm{~N}$; slip amplitude, $50 \mu \mathrm{m} ;$ total number of cycles, 1 million; environment, air; and temperatures, 296 and $823 \mathrm{~K}$.

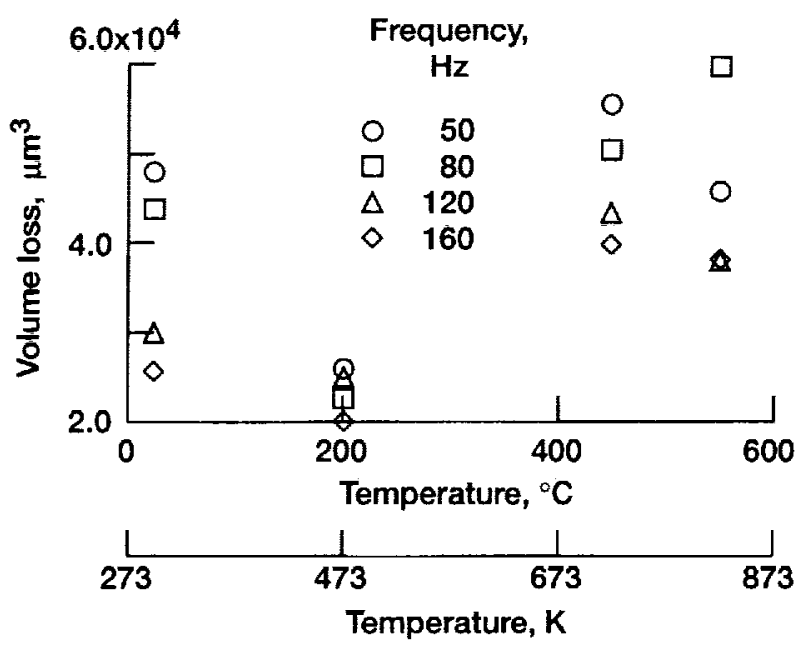

Figure 7-Wear volume loss of Ti-48.4l-2Cr-2Nb flat in contact with superalloy 718 pin in air as function of fretting temperature. Fretting conditions: load, $30 \mathrm{~N}$; slip amplitude, $50 \mathrm{um}$; total number of cycles, 1 million; environment, air; and fretting frequencies, $50,80,120$, and $160 \mathrm{~Hz}$.

Temperature influences the adhesion, deformation, and fracture behaviors of contacting materials in relative motion. It is known that temperature interacts with the fretting process in two ways: first, the rate of oxidation or corrosion increases with temperature; and second, the mechanical properties, such as hardness, of the materials are also temperature dependent [9]. Figure 7 presents the wear volume loss measured by optical interferometry as a function of temperature for $\mathrm{Ti}-48 \mathrm{Al}-2 \mathrm{Cr}-2 \mathrm{Nb}$ in contact with 
superalloy 718. Also, SEM images and EDS spectra were taken from the fretted Ti-48Al$2 \mathrm{Cr}-2 \mathrm{Nb}$ surfaces. The wear volume loss dropped to a low value at $473 \mathrm{~K}$. The worn surface at $473 \mathrm{~K}$ was predominantly oxide and relatively smooth. A protective oxide film prevented direct metal-to-metal contact and ensured, in effect, that a mild oxidative wear regime prevailed. However, fretting wear increased as the temperature was increased from 473 to $823 \mathrm{~K}$. The highest temperatures of 723 and $823 \mathrm{~K}$ resulted in oxide film disruption with crack generation, loose wear debris, and pitting of the $\mathrm{Ti}-48 \mathrm{Al}-2 \mathrm{Cr}-2 \mathrm{Nb}$ wear surface.

Figure 8 shows the wear volume loss measured by optical interferometry as a function of slip amplitude for Ti-48Al-2Cr-2Nb in contact with superalloy 718 . The fretting wear volume loss increased as the slip amplitude increased. Increases in amplitude tended to produce more metallic wear debris, causing severe abrasive wear in the contacting metals. Figure 9 presents a three-dimensional, optical interferometry image of the $\mathrm{Ti}-48 \mathrm{Al}-2 \mathrm{Cr}-2 \mathrm{Nb}$ wear scar at a slip amplitude of $200 \mu \mathrm{m}$ and a temperature of $296 \mathrm{~K}$. In the wear scar are large, deep grooves where the wear debris particles have scratched the $\mathrm{Ti}-48 \mathrm{Al}-2 \mathrm{Cr}-2 \mathrm{Nb}$ surface in the slip direction.

Figure 10 shows the measured wear volume loss as a function of load for Ti-48Al$2 \mathrm{Cr}-2 \mathrm{Nb}$ in contact with superalloy 718 at a temperature of $823 \mathrm{~K}$, a fretting frequency of $80 \mathrm{~Hz}$, and a slip amplitude of $50 \mu \mathrm{m}$ for 1 million cycles. The fretting wear volume loss generally increased as the load increased, generating more metallic wear debris in the contact area, the primary cause of abrasive wear in both $\mathrm{Ti}-48 \mathrm{Al}-2 \mathrm{Cr}-2 \mathrm{Nb}$ and superalloy 718 .

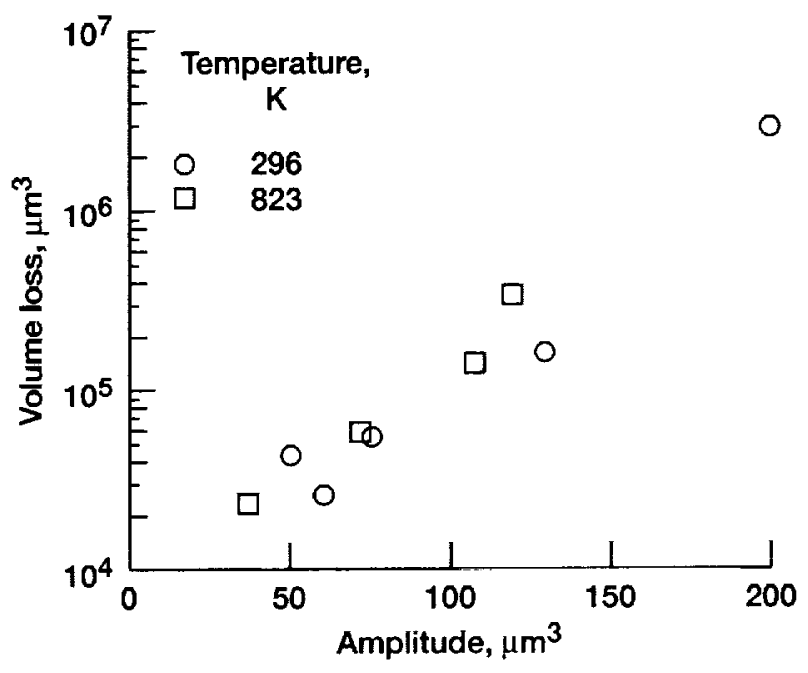

Figure 8-Wear volume loss of $\mathrm{Ti}-48 \mathrm{Al}-2 \mathrm{Cr}-2 \mathrm{Nb}$ flat in contact with superalloy 718 pin in air as function of slip amplitude. Fretting conditions: load, $30 \mathrm{~N}$; frequency, $50 \mathrm{~Hz}$; total number of cycles, I million; environment, air; and temperatures, 296 and $823 \mathrm{~K}$. 


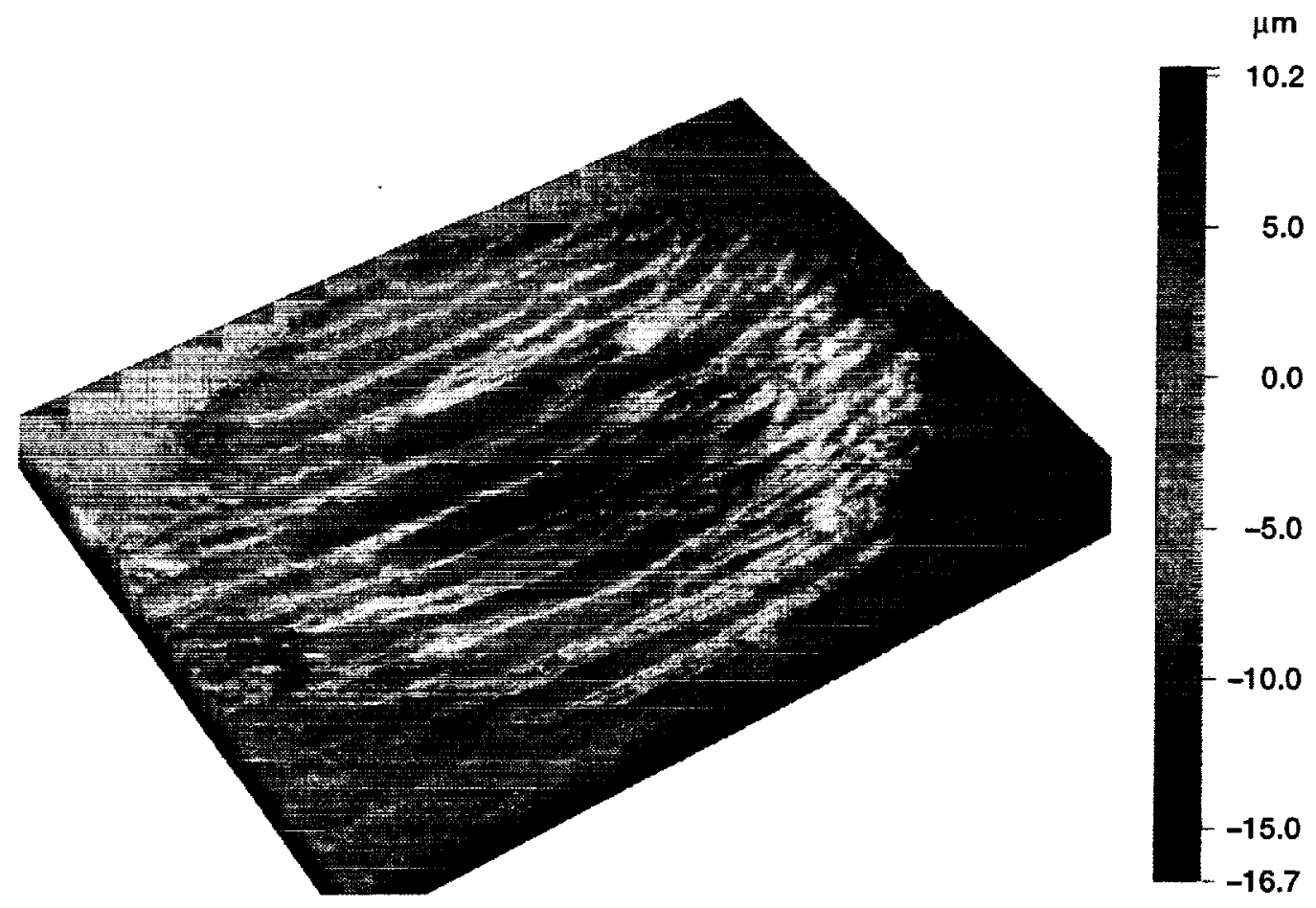

Figure 9-Wear scar on $\pi \mathrm{i}-48 \mathrm{Al}-2 \mathrm{Cr}-2 \mathrm{Nb}$ flat in contact with superalloy 718 pin, showing scratches. Fretting conditions: load, $30 \mathrm{~N}$; frequency, $50 \mathrm{~Hz}$; slip amplitude, $200 \mu \mathrm{m}$; total number of cycles, 1 million; environment, air; and temperature, $296 \mathrm{~K}$.

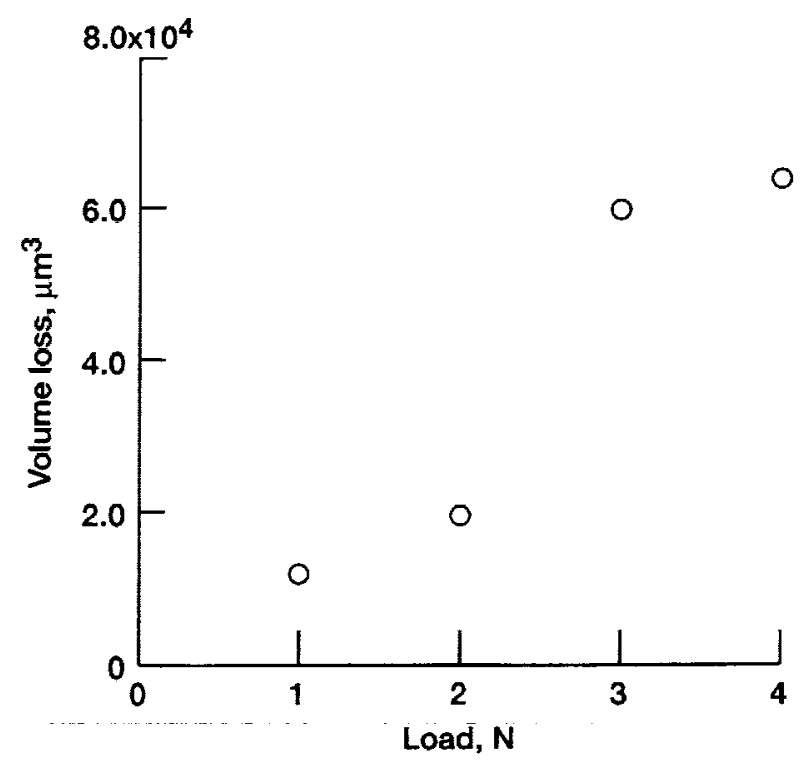

Figure 10-Wear volume loss of $7 \mathrm{i}-48 \mathrm{Al}-2 \mathrm{Cr}-2 \mathrm{Nb}$ flat in contact with superalloy 718 pin as function of load. Fretting conditions: frequency, $80 \mathrm{~Hz}$; slip amplitude, $50 \mu \mathrm{m}$; total number of cycles, I million; environment, air; and temperature, $823 \mathrm{~K}$. 


\section{Concluding Remarks}

The fretting behavior of $\gamma$-TiAl (Ti-48Al-2Cr-2Nb) in contact with nickel-base superalloy 718 in air at temperatures of 296 to $823 \mathrm{~K}$ was examined with the following results:

1. The Ti-48Al-2Cr-2Nb transferred to the superalloy 718 at all fretting conditions, such that from 10 to 50 percent of the superalloy 718 contacting surface area became coated with the Ti-48Al-2Cr-2Nb. The maximum thickness of the transferred Ti-48Al-2Cr$2 \mathrm{Nb}$ was approximately $20 \mu \mathrm{m}$. In reference experiments Ti-6Al-4V transferred to superalloy 718 under identical fretting conditions. Compared with $\mathrm{Ti}-48 \mathrm{Al}-2 \mathrm{Cr}-2 \mathrm{Nb}$ transfer, the degree of Ti-6Al-4V transfer was greater, such that from 30 to 100 percent of the superalloy 718 contacting surface area became coated with the Ti-6Al-4V. The thickness of the transferred $\mathrm{Ti}-6 \mathrm{Al}-4 \mathrm{~V}$ ranged up to $50 \mu \mathrm{m}$.

2. The wear scars produced on $\mathrm{Ti}-48 \mathrm{Al}-2 \mathrm{Cr}-2 \mathrm{Nb}$ contained metallic and oxide wear debris, scratches, plastically deformed asperities, cracks, and fracture pits.

3. Although oxide layers readily formed on the Ti-48Al-2Cr-2Nb surface at $823 \mathrm{~K}$, cracking readily occurred in the oxide layers both within and around the contact areas.

4. The wear volume loss of $\mathrm{Ti}-48 \mathrm{Al}-2 \mathrm{Cr}-2 \mathrm{Nb}$ generally decreased with increasing fretting frequency, increased with increasing temperature, and increased with increasing slip amplitude.

5. Mild oxidative wear and low wear volume were observed at $473 \mathrm{~K}$.

\section{References}

1. Miyoshi, K., "Foreword: Considerations in Vacuum Tribology (Adhesion, Friction, Wear, and Solid Lubrication in Vacuum)," Tribology International, Vol. 32, 1999, pp. 605-616.

2. Miyoshi, K., "Aerospace Mechanisms and Tribology Technology: Case Study," Tribology International, Vol. 32, 1999, pp. 673-685.

3. Tallian, T.E., "Failure Atlas for Hertz Contact Machine Elements," Fretting Wear, ASME Press, New York, 1992, pp. 141-154.

4. Waterhouse, R.B., "Plastic Deformation in Fretting Processes-a Review," Fretting Fatigue: Current Technology and Practices, ASTM STP 1367, D.W. Hoeppner, V. Chandrasekaran, and C.B. Elliot III, Eds., American Society for Testing and Materials, West Conshohocken, PA, 2000, pp. 3-18. 
5. Waterhouse, R.B., "Occurrence of Fretting in Practice and Its Simulation in the Laboratory," Materials Evaluation Under Fretting Conditions, ASTM STP 780, American Society for Testing and Materials, West Conshohocken, PA, 1982, pp. 3-16.

6. Kusner, D., Poon, C., and Hoeppner, D.W., "A New Machine for Studying Surface Damage due to Wear and Fretting," Materials Evaluation Under Fretting Conditions, ASTM STP 780, American Society for Testing and Materials, West Conshohocken, PA, 1982, pp. 17-29.

7. Satoh, T., "Influence of Microstructure on Fretting Fatigue Behavior of a Near-Alpha Titanium," Fretting Fatigue: Current Technology and Practices, ASTM STP 1367, D.W. Hoeppner, V. Chandrasekaran, and C.B. Elliot III, Eds., American Society for Testing and Materials, West Conshohocken, PA, 2000, pp. 295-307.

8. Lutynski, C., Simansky, G., and McEvily, A.J., "Fretting Fatigue of Ti-6Al-4V Alloy," Materials Evaluation Under Fretting Conditions, ASTM STP 780, American Society for Testing and Materials, West Conshohocken, PA, 1982, pp. 150-164.

9. Bill, R.C., "Review of Factors That Influence Fretting Wear," Materials Evaluation Under Fretting Conditions, ASTM STP 780, American Society for Testing and Materials, West Conshohocken, PA, 1982, pp. 165-182.

10. Hansson, T., et al., "High Temperature Fretting Fatigue Behavior in an XD $\gamma$-Base TiAl," Fretting Fatigue: Current Technology and Practices, ASTM STP 1367, D.W. Hoeppner, V. Chandrasekaran, and C.B. Elliot III, Eds., American Society for Testing and Materials, West Conshohocken, PA, 2000, pp. 65-79.

11. VanStone, R.H., Lawless, B.H., and Hartle, M., "Fretting in Ti-6Al-4V at Room Temperature," Proceedings of 5th National Turbine Engine High Cycle Fatigue $(H C F)$ Conference, 2000, Session 4, paper 1.

12. Chakravarty, S., et al., "The Effect of Surface Modification on Fretting Fatigue in Ti Alloy Turbine Components," JOM, Vol. 47, No. 4, 1995, pp. 31-35.

13. Hoeppner, D., Adibnazari, S., and Moesser, M.W., "Literature Review and Preliminary Studies of Fretting and Fretting Fatigue Including Special Applications to Aircraft Joints," DOT/FAA/CT-93/2, Defense Technical Information Center, Ft. Belvoir, VA, 1994.

14. Hutson A.L. and Nicholas, T., "Fretting Fatigue Behavior of Ti-6Al-4V Against Ti6Al-4V Under Flat-on-Flat Contact With Blending Radii," Fretting Fatigue: Current Technology and Practices, ASTM STP 1367, D.W. Hoeppner, V. Chandrasekaran, and C.B. Elliot III, Eds., American Society for Testing and Materials, West Conshohocken, PA, 2000, pp. 308-321.

15. Miyoshi, K., et al., "Sliding Wear and Fretting Wear of Diamondlike Carbon-Based, Functionally Graded Nanocomposite Coatings," Wear, Vol. 225-229, 1999, pp. 65-73.

16. Hunt, M.W. (Ed.), Materials Selector 1993, Materials Engineering, Penton Publishing, Cleveland, $\mathrm{OH}, 1992$.

17. Donachie, M.J. (Ed.), Titanium and Titanium Alloys, Source Book, American Society for Metals, Metals Park, OH, 1982. 
Public reporting burden for this collection of information is estimated to average 1 hour per response, Including the time for reviewing instructions, searching existing data sources, gathering and maintaining the data needed, and completing and reviewing the collection of information. Send comments regarding this burden estimate or any other aspect of this Davis Highway, Suite 1204, Arlington, VA 22202-4302, and to the Office of Management and Budget, Paperwork Reduction Project (0704-0188), Washington, DC 20503.

\begin{tabular}{|l|l|l}
\hline 1. AGENCY USE ONLY (Leave blank) & $\begin{array}{c}\text { 2. REPORT DATE } \\
\text { November } 2001\end{array}$ & $\begin{array}{r}\text { 3. REPORT TYPE AND DATES COVERED } \\
\text { Technical Memorandum }\end{array}$
\end{tabular}

\section{TITLE AND SUBTITLE}

Evaluation of Ti-48Al-2Cr-2Nb Under Fretting Conditions

6. AUTHOR(S)

\section{FUNDING NUMBERS}

$$
\text { WU-708-24-13-00 }
$$

Kazuhisa Miyoshi, Bradley A. Lerch, Susan L. Draper, and Sai V. Raj

\section{PERFORMING ORGANIZATION NAME(S) AND ADDRESS(ES)}

National Aeronautics and Space Administration

John H. Glenn Research Center at Lewis Field

Cleveland, Ohio 44135-3191

8. PERFORMING ORGANIZATION REPORT NUMBER

$$
\text { E-13006-1 }
$$

\section{SPONSORING/MONITORING AGENCY NAME(S) AND ADDRESS(ES)}

National Aeronautics and Space Administration

Washington, DC 20546-000I

10. SPONSORINGMONITORING AGENCY REPORT NUMBER

NASA TM-2001-211205

ASTM STP 1425

\section{SUPPLEMENTARY NOTES}

Prepared for the Third International Symposium on Fretting Fatigue sponsored by the American Society for Testing and Materials, Nagaoka-shi, Japan, May 15-18, 200I. Responsible person, Kazuhisa Miyoshi, organization code 5160, 216-433-6078.

12a. DISTRIBUTION/AVAILABILITY STATEMENT

12b. DISTRIBUTION CODE

Unclassified - Unlimited

Subject Category: 26

Distribution: Nonstandard

Available electronically at http://gltrs.grc.nasa.gov/GLTRS

This publication is available from the NASA Center for AeroSpace Information, 301-621-0390.

\section{ABSTRACT (Maximum 200 words)}

The fretting behavior of Ti-48Al-2Cr-2Nb $(\gamma$-TiAl) in contact with the nickel-base superalloy 718 was examined in air at temperatures from 296 to $823 \mathrm{~K}\left(23\right.$ to $\left.550^{\circ} \mathrm{C}\right)$. The interfacial adhesive bonds between Ti-48Al-2Cr- $2 \mathrm{Nb}$ and superalloy 718 were generally stronger than the cohesive bonds within $\mathrm{Ti}-48 \mathrm{Al}-2 \mathrm{Cr}-2 \mathrm{Nb}$. The failed $\mathrm{Ti}-48 \mathrm{Al}-2 \mathrm{Cr}-2 \mathrm{Nb}$ debris subsequently transferred to the superalloy 718 . In reference experiments conducted with Ti-6Al-4V against superalloy 718 under identical fretting conditions, the degree of transfer was greater for Ti- $6 \mathrm{Al}-4 \mathrm{~V}$ than for Ti- $48 \mathrm{Al}-2 \mathrm{Cr}-2 \mathrm{Nb}$. Wear of $\mathrm{Ti}-48 \mathrm{Al}-2 \mathrm{Cr}-2 \mathrm{Nb}$ generally decreased with increasing fretting frequency. The increasing rate of oxidation at elevated temperatures led to a drop in wear at $473 \mathrm{~K}$. However, fretting wear increased as the temperature was increased from 473 to $823 \mathrm{~K}$. At 723 and $823 \mathrm{~K}$, oxide film disruption generated cracks, loose wear debris, and pits on the Ti- $48 \mathrm{Al}-2 \mathrm{Cr}-2 \mathrm{Nb}$ wear surface. Both increasing slip amplitude and increasing load tended to produce more metallic wear debris, causing severe abrasive wear in the contacting metals.

\section{SUBJECT TERMS}

Materials; Ti-48Al-2Cr-2Nb; Fretting wear; Fatigue; Oxidation; High temperature; Ni-base superalloy 718

\begin{tabular}{|c|c|}
\hline $\begin{array}{c}\text { 17. SECURITY CLASSIFICATION } \\
\text { OF REPORT } \\
\text { Unclassified }\end{array}$ & $\begin{array}{c}\text { 18. SECURITY CLASSIFICATION } \\
\text { OF THIS PAGE } \\
\text { Unclassified }\end{array}$ \\
\hline
\end{tabular}

\section{SECUAITY CLASSIFICATION} OF ABSTRACT Unclassified 